\title{
cAMP stimulates the C/EBP-related transcription factor rNFIL-6 to trans-locate to the nucleus and induce c-fos transcription
}

\author{
Richard Metz and Edward Ziff \\ Howard Hughes Medical Institute, Department of Biochemistry and Kaplan Cancer Center, New York University \\ Medical Center, New York, New York 10016 USA
}

The c-fos serum response element (SRE) is a multifunctional regulatory region of the c-fos promoter that responds to a variety of inducers. Recently, we have demonstrated that the SRE binds the C/EBP-related transcription factor rat NFIL-6 (rNFIL-6). In this study we show that rNFIL-6 is regulated by the cAMP second messenger pathway in the rat pheochromocytoma PC12 cell line. Following forskolin treatment, rNFIL-6 binding to the SRE is increased, and the factor becomes phosphorylated and undergoes a trans-location to the nucleus. In transient cotransfection assays, rNFIL-6 is capable of trans-activating the c-fos promoter in a manner dependent on the SRE. These data show that rNFIL-6 undergoes a novel activation in which cAMP-induced nuclear trans-location allows rNFIL-6 to bind to the SRE and contribute to c-fos activation. We propose that rNFIL-6 is an additional regulatory component of the c-fos gene, which provides cAMP responsiveness to the multifunctional SRE.

[Key Words: C/EBP; rNFIL-6; c-fos; SRE; transcription]

Received May 7, 1991; revised version accepted July 29, 1991.

The cellular proto-oncogene $\mathrm{c}$-fos is a member of a class of immediate early response genes (Almendral et al. 1988) whose transcription is rapidly and transiently induced by a wide variety of transmembrane signaling agents (Greenberg and Ziff 1984; for review, see Curran 1988). Like several genes of this class, c-fos encodes a nuclear protein that is likely to participate in long-term adaptive changes in the cell as a result of the initial stimulus. Several elements within the $5^{\prime}$-flanking region of the gene have been defined that are targets for stimulatory agents. One such element, the serum response element (SRE) (Treisman 1985), mediates induction by serum, a number of polypeptide growth factors, 12-O-tetradecanoylphorbol-13 acetate (TPA), and cAMP (Gilman et al. 1986; Treisman et al. 1986; Fisch et al. 1987, 1989a,b; Greenberg et al. 1987; Gilman 1988; Stumpo et al. 1988; Siegfried and Ziff 1989) and is recognized by at least five protein factors (Gilman et al. 1986; Treisman 1986; Greenberg et al. 1987; Ryan et al. 1989; Shaw et al. 1989; Metz and Ziff 1991). One of these, the serum response factor (SRF), binds to the sequence element $\mathrm{CC}(\mathrm{A} / \mathrm{T})_{6} \mathrm{GG}$ [termed the CArG box (Minty and Kedes 1986)] within the SRE (Treisman et al. 1986; Boxer et al. 1989; Rivera et al. 1990). Mutations of the SRE that disrupt SRF binding also block serum inducibility of the c-fos promoter (Greenberg et al. 1987). The binding of SRF to CArG box elements in other serum-responsive genes (Mohun et al.
1987; Chavrier et al. 1989; Christy and Nathans 1989| suggests that at least one pathway is common among these classes of serum-responsive promoters. SRF has been purified to homogeneity (Prywes and Roeder 1987; Schröter et al. 1987; Treisman et al. 1987; Metz et al. 1988), and its cDNA has been cloned (Norman et al. 1988). However, very little is known about the specific function of SRF, and it seems clear that other factors contribute to the control of the c-fos SRE. SRF modulates the binding of an additional $62-\mathrm{kD}$ protein component, termed ternary complex factor or p62 ${ }^{\mathrm{TCF}}$ (Shaw et al. 1989; Schröter et al. 1990). This factor, which is required for protein kinase C activation through the SRE /Graham and Gilman 1991), requires contact with nucleotide sequences adjacent to the CArG element as well as contact with SRF to bind stably to the SRE. The sequences necessary for the SRF/p62 ${ }^{\mathrm{TCF}}$ complex formation are not conserved in the dyad symmetry element (DSE)-like elements in the NGFIA, Krox24, and $\beta$-actin genes, suggesting that the c-fos SRE may contain regulatory elements not common to other serum-responsive genes.

Enhancers often harbor a number of overlapping enhanson elements (Dynan 1989). The SRE is composed of at least two independent transcriptional subelements: (1) a 20-bp DSE positioned from residues -317 to -298 ; and (2) a region comprising residues -303 to -281 , the c-fos AP-1 site (FAP), with sequence homology to the 
consensus-binding sites for the transcription factors AP-1 (Lee et al. 1987) and cAMP response element binding (CREB) (Montminy et al. 1986, 1987). Both the FAP and DSE are responsive to cAMP (Fisch et al. 1989b), a second messenger employed by a number of polypeptide growth factors for signal transduction. An oligonucleotide spanning the FAP element displays enhanson activity, whereby it can confer cAMP-inducible and constitutive activity upon a heterologous promoter when transfected into PC12 or HeLa cells, respectively /Velcich and Ziff 1990). The FAP site binds the c-Fos/c-Jun complex, CREB, and activating transcription factor (ATF), all factors that may provide a cAMP response (Hyman et al. 1988; Sassone-Corsi et al. 1988a,b). However, neither the basis for cAMP responsiveness of the DSE nor the relationship between this response and the FAP site is evident. Recently, we have cloned a cDNA-encoding factor, found to be the rat homolog of NFIL-6 (rNFIL6; Chang et al. 1990; Descombes et al. 1990; Poli et al. 1990), which specifically binds to the c-fos SRE (Metz and Ziff 1991). rNFIL-6 recognizes the sequence ATTAGGACAT that is located within the c-fos SRE between the CArG and FAP elements. NFIL- 6 has been shown to be involved in the activation of the interleukin-6 (IL-6) gene in fibroblasts following interleukin-1 (IL-1) or IL-6 stimulation (Akira et al. 1990), which may involve a cAMP-dependent pathway (Zhang et al. 1988). Taken together, these data support a hypothesis in which rNFIL- 6 binds to the DSE and mediates stimulation of c-fos through a cAMP pathway. Both NFIL-6 and rNFIL- 6 contain a b-zip domain that is highly homologous to the liver transcription factor CCAAT/enhancer-binding protein $(\mathrm{C} / \mathrm{EBP})$, and both recognize C/EBP consensus-binding sequences (Akira et al. 1990; Metz and Ziff 1991). Such a sequence, which is identical to the C/EBP-binding site in the transthyretin gene (Costa et al. 1988), is located within the SRE overlapping a portion of the CArG element (Fig. 1). The C/EBP-binding site has been suggested to mediate cAMP control of certain promoters (McKnight et al. 1989). Recently, Park et al. (1990) have demonstrated that C/EBP can interact with a cAMP-re-

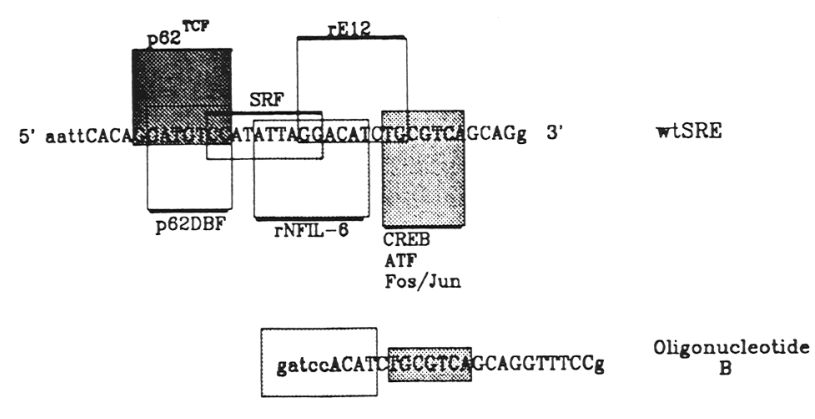

Figure 1. Multiple elements within the SRE. The wild-type SRE sequence contains nucleotide sequences that interact with at least six different polypeptides, illustrated by boxes: SRF, p62DBF, p62 ${ }^{\mathrm{TCF}}$, CREB or Fos/Jun family members, rE12, and rNFIL-6. Oligonucleotide B contains the FAP site and half of the rNFIL-6-binding site. sponsive element, the CRE. In addition, the activation of the IL- 6 gene following IL-1 stimulation requires the binding of NFIL-6 for its activation (Akira et al. 1990) and may also require stimuli provided by the cAMP second messenger pathway (Zhang et al. 1988). Taken together with the observations that oligonucleotides containing both DSE and FAP sequences bind rNFIL-6 (Metz and Ziff 1991) and respond to cAMP signals (Fisch et al. 1989b), we asked whether rNFIL-6 may be activated by cAMP-responsive signals.

In this report we demonstrate that forskolin treatment of $\mathrm{PCl} 2$ cells induces the level of a nucleoprotein, which forms a complex with the SRE, and that this complex contains rNFIL-6. The forskolin-dependent increase in the binding of rNFIL- 6 is independent of new protein synthesis and is accompanied by an increase in rNFIL- 6 phosphorylation and nuclear localization. Using a transient cotransfection assay, we demonstrate that rNFIL-6 can activate reporter constructs containing the DSE and FAP oligonucleotides. We also show that in HeLa cells, which are transformed, this pathway may be constitutively activated: A protein antigenically related to NFIL-6 is localized in the nucleus and exhibits DNA binding to the SRE in untreated cells. From the data reported here, we propose a model in which rNFIL- 6 interacts with the SRE and activates transcription in response to an increase in intracellular levels of cAMP. In some transformed cell lines, such as HeLa, this pathway may be constitutively activated, modifying the control of the c-fos promoter.

\section{Results}

\section{rNFIL- 6 binding is enhanced} following forskolin treatment

To analyze the effects of cAMP on the binding of rNFIL6 , we assayed SRE-binding activity in nuclear extracts prepared from either untreated or forskolin-treated $(30$ min) PC12 cells. With both extracts, two specific complexes are detected, complex I and complex II (Fig. 2). A third nonspecific complex is present in every lane and does not compete with any of the competition DNAs. To discriminate which proteins might be present in these complexes we determined the abilities of a series of mutant SRE oligonucleotides, PR1-PR7, tested previously for rNFIL- 6 binding, to compete for the formation of these complexes (Fig. 1). Mutant oligonucleotides PR4PR7 (Fig. 2B, lanes 3-6, 12-15), which disrupted the CArG box (the consensus SRF-binding site), did not significantly compete the formation of complex I using either extract. Consistent with the likelihood that complex I contains bound SRF, anti-SRF antibody disrupts its specific formation (data not shown).

Formation of complex II in the untreated cell extract was competed by all of the PR mutant oligonucleotides (Fig. 2B, lanes 2-9) and therefore results from a factor that binds outside the rNFIL- 6 and SRF-binding sites. In contrast, a protein-DNA complex present in complex II derived from nuclear extracts of the forskolin-treated 
A

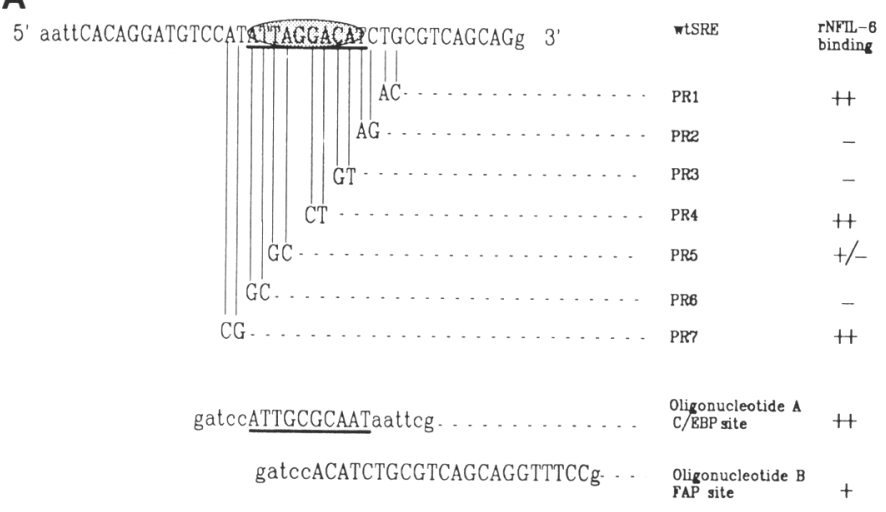

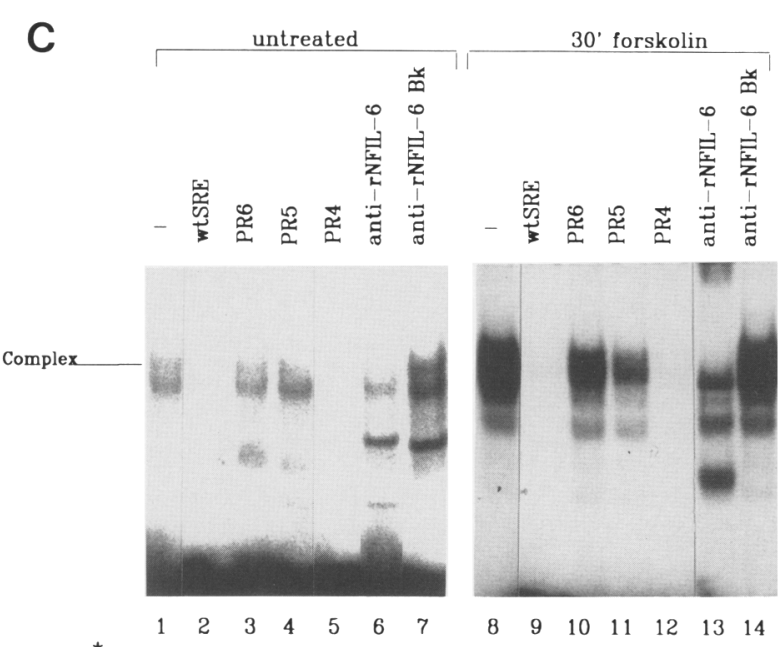

oligo $A^{*}$
B
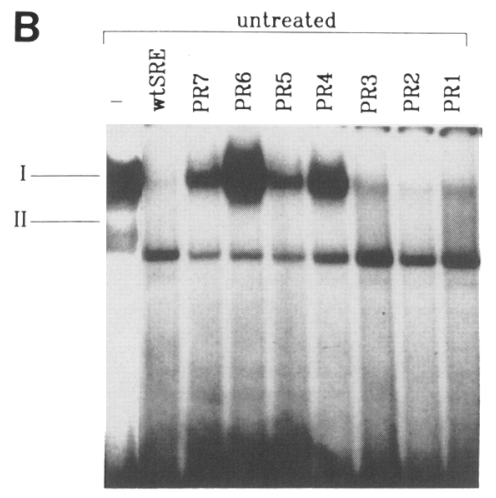

$\begin{array}{lllllllll}1 & 2 & 3 & 4 & 5 & 6 & 7 & 8 & 9\end{array}$

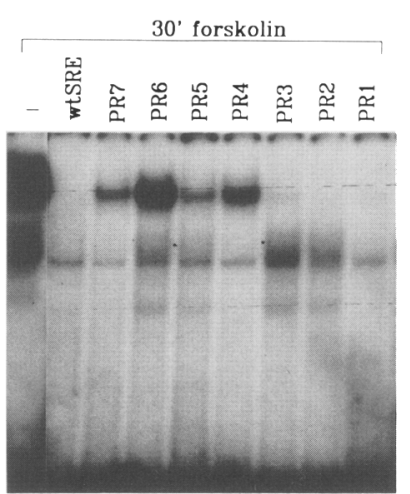

$\begin{array}{llllllllll}10 & 11 & 12 & 13 & 14 & 15 & 16 & 17 & 18\end{array}$

WLSE

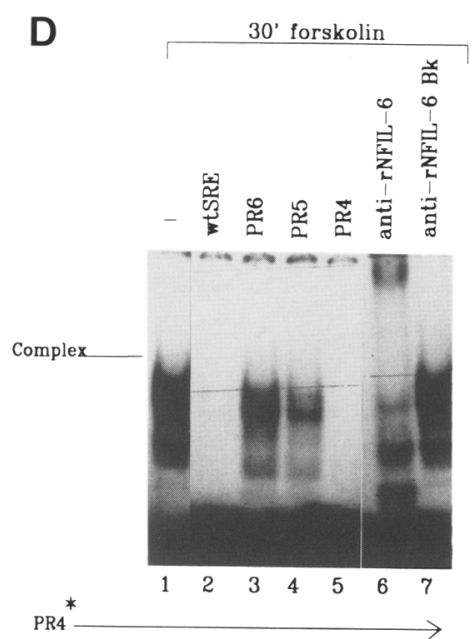

Figure 2. A rNFIL-6-SRE complex is present in PC12 nuclear extracts following forskolin treatment. $(A)$ The various SRE mutant oligonucleotides used as competitors in shift assays and oligonucleotide $\mathrm{A}$, which contains the sequences of a palindromic C/EBP consensus-binding site. A summary of their abilities to bind rNFIL- 6 is indicated $(+$ or -$)$ The shaded ellipse represents the rNFIL6-binding site in the SRE and C/EBP oligonucleotide probes. Nuclear extracts from PC12 cells that were untreated or treated with forskolin for $30 \mathrm{~min}$ were incubated for $30 \mathrm{~min}$ with the indicated ${ }^{32} \mathrm{P}$-labeled oligonucleotides, wild-type SRE (wtSRE) (B), oligonucleotide A $(C)$, or PR4 (D) in the absence or presence of a 100 molar (20 ng) excess of the unlabeled competitor oligonucleotide indicated above each lane. Protein-DNA complexes were analyzed on a $5 \%$ nondenaturing polyacrylamide gel. Nuclear extracts from untreated or forskolin-induced PC12 cells were incubated for $30 \mathrm{~min}$ at $0^{\circ} \mathrm{C}$ with $200 \mathrm{ng}$ of either anti-rNFIL-6 antibody $(C$, lanes 6,$13 ; D$, lane 6) or anti-rNFIL-6 antibody preabsorbed with an excess $(1 \mu \mathrm{g})$ of trpE-rNFIL-6 $(C$, lanes 7,$14 ; D$, lane 7$)$, prior to DNA-binding reaction.

cells was not competed by the mutant oligonucleotides PR6, PR5, PR3, and PR2 (Fig. 2B, lanes 13,14,16,17, respectively), which have disruptions in the rNFIL- 6 site. Therefore, the nature of complex II changes following forskolin treatment of $\mathrm{PC} 12$ cells, implying that the protein that binds to the rNFIL- 6 site is regulated in response to forskolin treatment. The difficulty in detecting rNFIL- 6 binding with the SRE probe is probably because of the binding of several competing factors. In agreement, nuclear extracts from induced cells formed a stronger complex with oligonucleotide A (Fig. 2A), which contains a strong consensus-binding site for rNFIL-6 than extracts from untreated PC12 cells (Fig. $2 \mathrm{C}$, lanes 1,8$)$. The complexes formed by extracts from either induced or untreated cells with oligonucleotide A are competed by the wild-type SRE (wtSRE) oligonucleotide (Fig. 2C, lanes 2,9), but failed to be competed by the SRE oligonucleotide probes containing mutations in the rNFIL-6 site (Fig. 2C, lanes 3,4,10,11).

When compared with complex II formed with the SRE probe, the complex formed with oligonucleotide A was more intense. Also, we do not detect a complex with the SRE probe that might contain both SRF and rNFIL-6. Together with the fact that the recognition sites for SRF and rNFIL- 6 overlap by 5 nucleotides, these data suggest that steric interference may prevent simultaneous binding of SRF and rNFIL-6. This is supported by the observation that the mutant oligonucleotide PR4, in which 
the SRF-binding site is disrupted, gives a higher level of complex II with induced extracts than does the wild-type SRE oligonucleotide probe in Figure 2D.

\section{Anti-rNFIL-6 antibody disrupts complexes between SRE DNA and the PC12 cell protein}

To confirm that complex II contains rNFIL-6, we prepared an affinity-purified rabbit anti-rNFIL- 6 antibody using a trpE-rNFIL- 6 fusion protein antigen and assayed its ability to disrupt complex II. The anti-rNFIL- 6 antibody disrupts the prominent and slowest-migrating protein-DNA complex formed between PC12 nuclear extracts and either oligonucleotide A or the PR4 oligonucleotide (Fig. 2C, lanes 6,13; Fig. 2D, lane 7, respectively), neither of which forms a complex with SRF. We note that the anti-rNFIL-6 antibody does not eliminate all of the protein-DNA complexes. Often there is a faster-migrating complex in the lane containing the antibody. The nature of the faster-migrating band has not been established; however, these data suggest that the rNFIL- 6 site interacts with at least one other component that is not immunologically related to rNFIL-6. Preabsorbing the antibody with an excess of trpE-rNFIL- $6 \mathrm{fu}$ sion protein antigen prevents the disruption of the prominent complex, as well as the appearance of the faster-

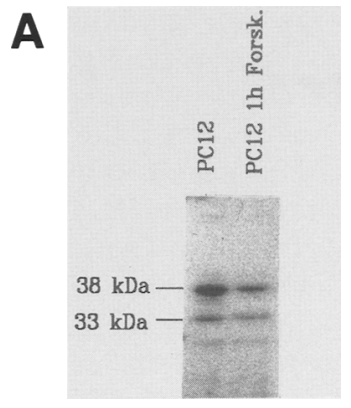

Figure 3. Anti-rNFIL-6 antibody recognizes two proteins, 33 and $38 \mathrm{kD}$, in extracts from ${ }^{35} \mathrm{~S}$ - or ${ }^{32} \mathrm{P}$-labeled PC12 cells. $(A)$ Whole-cell extract from untreated or forskolin-treated PC12 cells was fractionated by SDS-PAGE and assayed for the presence of rNFIL- 6 by Western blot analysis. $(B)$ PC1 2 cells labeled with $\left[{ }^{35} \mathrm{~S}\right]$ methionine for $4 \mathrm{hr}$ prior to harvesting either directly (lanes 1-4) or following treatment with forskolin for $60 \mathrm{~min}$ (lanes 5-8). Each extract was divided into four equal aliquots and used for immunoprecipitation with $200 \mathrm{ng}$ of affinity-purified anti-rNFIL- 6 antibody. Some samples were boiled for $5 \mathrm{~min}$ prior to immunoprecipitation (lanes 2,3,6,7). (Lanes $3,4,7,8$; blocked lanes) anti-rNFIL- 6 antibody was first preabsorbed with trpE-rNFIL-6 fusion protein before it was added to the labeled extract. The immunoprecipitated products were analyzed on a $12 \%$ SDS-polyacrylamide gel. The mobilities and sizes for the molecular mass markers are indicated. $(C)$ PC12 cells were labeled with $\left.{ }^{32} \mathrm{P}\right]$ orthophosphate for $4 \mathrm{hr}$ prior to harvesting and were either untreated or treated with forskolin for 30,60 , or 120 min, as indicated. Immunoprecipitations were performed and analyzed as described in $B$. Immunoprecipitations of heat-denatured extracts (lanes 2,5,8,11) or those with antigen-blocked anti-rNFIL-6 antibody (lanes 3,6,9,12) are indicated. migrating complex, confirming the specificity of the antibody (Fig. 2C, lanes 7,14; Fig. 2D, lane 7). The specificity of the antibody for rNFIL- 6 was confirmed by Western analysis of $\mathrm{PC1} 2$ extract, in which only two protein species of 38 and $33 \mathrm{kD}$ corresponding to rNFIL-6 were recognized (see below). We can rule out the possibility that the antibody is recognizing C/EBP in complex II because preabsorbing the anti-rNFIL- 6 antibody with trpE-C/EBP fusion protein does not prevent the antibody from disrupting complex II. In addition, C/EBP mRNA is not detected in PC12 cells by Northern analysis /data not shown).

\section{rNFIL-6 is part of a heteromeric complex} that is phosphorylated in response to increased intracellular levels of $c A M P$

To explore further the possibility that rNFIL- 6 is under cAMP control, we asked whether forskolin treatment affected the synthesis of the rNFIL- 6 protein. In the Western blot experiment in Figure 3A, two proteins $(38$ and $33 \mathrm{kD}$ ) are recognized by the anti-rNFIL- 6 antibody in both untreated and forskolin-treated PC12 cell extracts. Their apparent molecular masses are consistent with those of encoded products predicted from the amino acid sequence (Metz and Ziff 1991) if translation
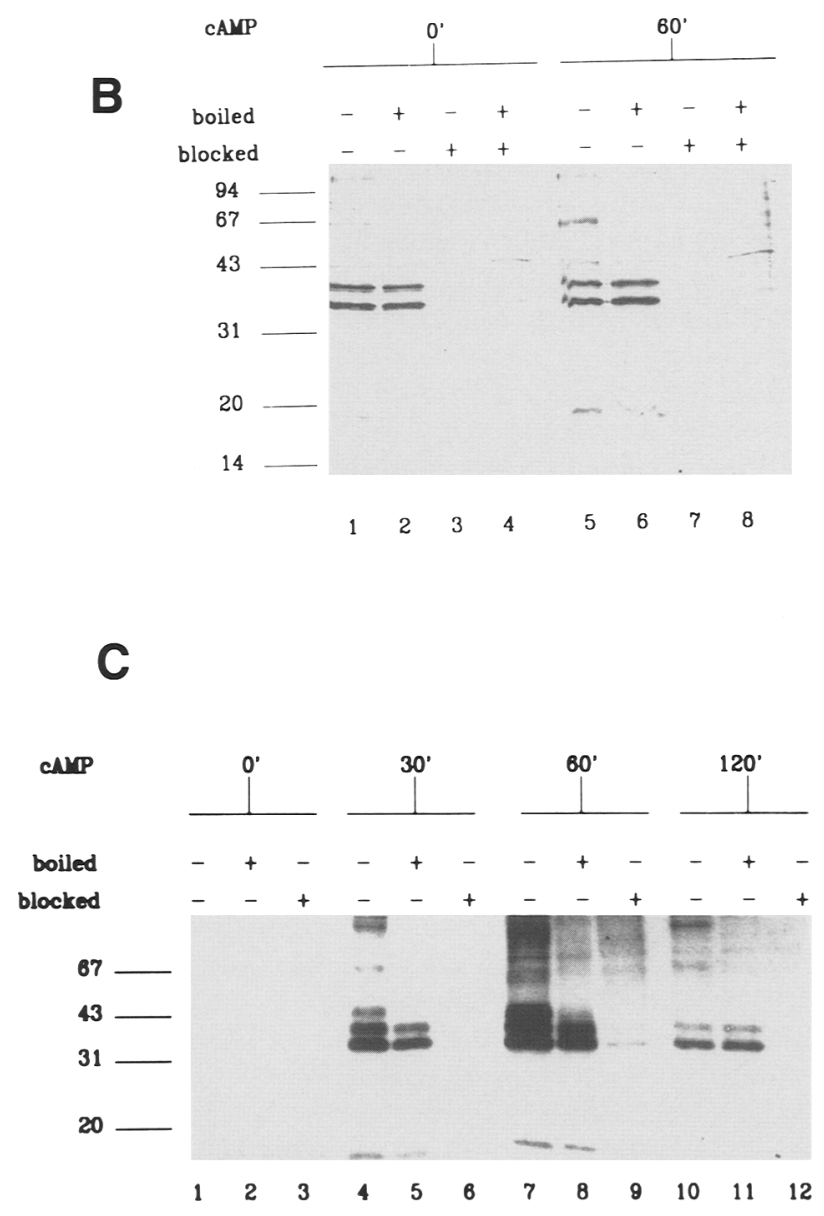
were to initiate at both of the first two AUGs of the mRNA. Indeed, translation in vitro of the complete mRNA yields two polypeptides, 33 and $38 \mathrm{kD}$, whereas in vitro translation containing only the second AUG gives a single $33-\mathrm{kD}$ polypeptide, suggesting that translation initiation can occur at both AUGs (data not shown).

A common mechanism for gene induction following cell stimulation is the increase in particular kinase activities that modify and activate regulatory molecules. To determine whether rNFIL-6 is phosphorylated following forskolin treatment we immunoprecipitated rNFIL-6 from lysates of $\mathrm{PC} 12$ cells labeled with $\left[{ }^{35} S \mid\right.$ methionine or ${ }^{32} \mathrm{PO}_{4}$, and incubated in the presence or absence of forskolin. Immunoprecipitation of protein from $\left[{ }^{35} \mathrm{~S}\right] \mathrm{me}-$ thionine-labeled cells shown in Figure 3B revealed two major protein species, whose apparent molecular masses, 38 and $38 \mathrm{kD}$, are the same as those seen by Western analysis in Figure 3A. The rates of synthesis of these proteins apparently do not change significantly following forskolin treatment because there is little change in $\left[{ }^{35} \mathrm{~S}\right]$ methionine incorporation in response to forskolin, consistent with the results of Western analysis. Because the levels of these proteins do not change following treatment with forskolin, the increase of complex II is not dependent on the increased synthesis of rNFIL- 6 . This finding is consistent with the report by Velcich and Ziff (1990) that protein synthesis inhibitors do not block the cAMP induction of transcription dependent on a triplicated FAP oligonucleotide, which contains a partial but functional rNFIL-6 site (Metz and Ziff 1991). In contrast, the level of ${ }^{32} \mathrm{PO}_{4}$ labeling of proteins immunoprecipitated by anti-rNFIL- 6 antibodies changes dramatically following forskolin treatment. As shown in the pulselabeling experiment of Figure 3C, both rNFIL-6 peptides undergo forskolin-dependent phosphorylation, which reaches a maximum at $1-\mathrm{hr}$ poststimulation. Because the levels of rNFIL-6 in the cell do not change during this period, we conclude that rNFIL- 6 is modified post-translationally by a kinase that responds to increased intracellular levels of cAMP. It is unlikely that the antibody is detecting C/EBP or other proteins sharing homology with the b-zip domain of C/EBP because preabsorption with a trpE-C/EBP fusion protein did not alter the results (data not shown).

In addition to the prominent $33-$ and $38-\mathrm{kD}$ polypeptides, ${ }^{35} \mathrm{~S}$-labeling identifies a $64-\mathrm{kD}$ protein and ${ }^{32} \mathrm{PO}_{4}$ labeling identifies a $43-\mathrm{kD}$ phosphoprotein, which immunoprecipitate with the anti-rNFIL- 6 antibody, respectively, in Figure 3, B and C. The $43-\mathrm{kD}$ phosphoprotein and $64-\mathrm{kD}$ protein are detected only in stimulated cells. If extracts are boiled prior to the immunoprecipitation, the $43-$ and $64-\mathrm{kD}$ proteins are absent from the immunoprecipitate although the $38-$ and $33-\mathrm{kD}$ proteins are still present. Western blot analysis (Fig. 3A) of untreated or forskolin-stimulated PC12 extract with anti-rNFIL-6 shows no reactive proteins in the $43-$ and $64-\mathrm{kD}$ size ranges. These data suggest that the $43-$ and $64-\mathrm{kD}$ proteins are rNFIL-6-associated proteins and not products cross-reacting with anti-rNFIL- 6 . Because the $43-\mathrm{kD}$ pro- tein is detected only in forskolin-treated ${ }^{32} \mathrm{PO}_{4}$-labeled cells it is not possible to determine whether its phosphorylation or association with rNFIL- 6 is in response to forskolin treatment. Similarly, it cannot be determined whether the expression of the $64-\mathrm{kD}$ protein and subsequent association with rNFIL- 6 are regulated by forskolin or whether expression is continuous and only its association with rNFIL-6 is induced by forskolin.

\section{rNFIL-6 induces transcriptional activity}

To investigate whether recombinant rNFIL-6 can transactivate through the FAP- or DSE-containing oligonucleotides or the complete c-fos promoter, we used cotransfection to express the rNFIL- 6 gene product in the presence of the fos-CAT (chloramphenicol acetyl transferase) reported constructs shown in Figure $\overline{4} \mathrm{~A}$. The constructs (pFC700, pFC53, pFCFAP, and pFCDSE) contained 700 bases of the $c$-fos promoter $5^{\prime}$-flanking region, no enhancer element, or the FAP- or DSE-containing oligonucleotides, respectively, in front of the minimal promoter of the c-fos gene fused to the CAT gene (described in Fisch et al. 1989b). The promoterless control was the plasmid PUCCAT. Two expression vectors with rNFIL-6 sequences transcribed from the Rous sarcoma virus long terminal repeat (RSV LTR) were constructed from RSV CAT (Gorman et al. 1982). RSV $\Delta$ rNFIL-6 + ) and RSV $\Delta$ rNFIL-6| - | expressed the transcripts from a partial cDNA clone 21 , lacking 282 nucleotides from the $5^{\prime}-$ coding region, in the sense and anti-sense orientations, respectively (Fig. 4A). An in-frame translational initiation site was supplied in these constructs to allow proper expression of the amino-terminal truncated rNFIL- 6 protein. Vector RSVrNFIL-6 expressed the complete coding region of rNFIL- 6 and utilized its own translational start codons. In Figure 4B, NIH 3T3 cells were cotransfected with combinations of reporter constructs and rNFIL-6 expression vectors. Vectors with either the DSE or the FAP oligonucleotides as a target were activated by cotransfection with RSVrNFIL- 6 in lanes 7 and 8 and RSV $\Delta$ rNFIL- $6|+|$ in lanes 12 and 13 , but were unaffected by the control, RSV $\Delta$ rNFIL-6(-1) in lanes 2 and 3 . The target vectors lacking the DSE or FAP oligonucleotides were not induced significantly. The construct, pFCDSE, is consistently more highly induced by rNFIL- 6 expression than pFCFAP. This difference probably results from the lower affinity of rNFIL- 6 for the FAP oligonucleotide. It is possible, however, that other FAP oligonucleotidebinding proteins may stabilize rNFIL- 6 binding. In vitrosynthesized $\triangle \mathrm{rNFIL}-6$ is able to bind the FAP oligonucleotide simultaneously with in vitro-synthesized ATF1, a transcription factor that recognizes the CRE consensus site in the FAP oligonucleotide (R. Metz and E. Ziff, unpubl.).

The plasmid RSVrNFIL-6, which expresses the complete rNFIL-6-coding region, activates both the DSE- and FAP-containing constructs. However, it does so to a lesser extent than RSVArNFIL-6|+) (Fig. 4B, cf. lanes 7 and 8 with 12 and 13). This can be explained in part by the fact that expression of rNFIL- 6 from RSVrNFIL-6 is 
about twofold lower in the transfected cells than the expression of $\Delta$ rNFIL- 6 from RSV $\Delta$ rNFIL- 6 , as shown by RNase protection analysis of the transfected cells (data not shown). We have not yet determined whether the lower expression of RSVrNFIL-6 accounts fully for the decreased trans-activation. Possibly the complete pro-

\section{A}

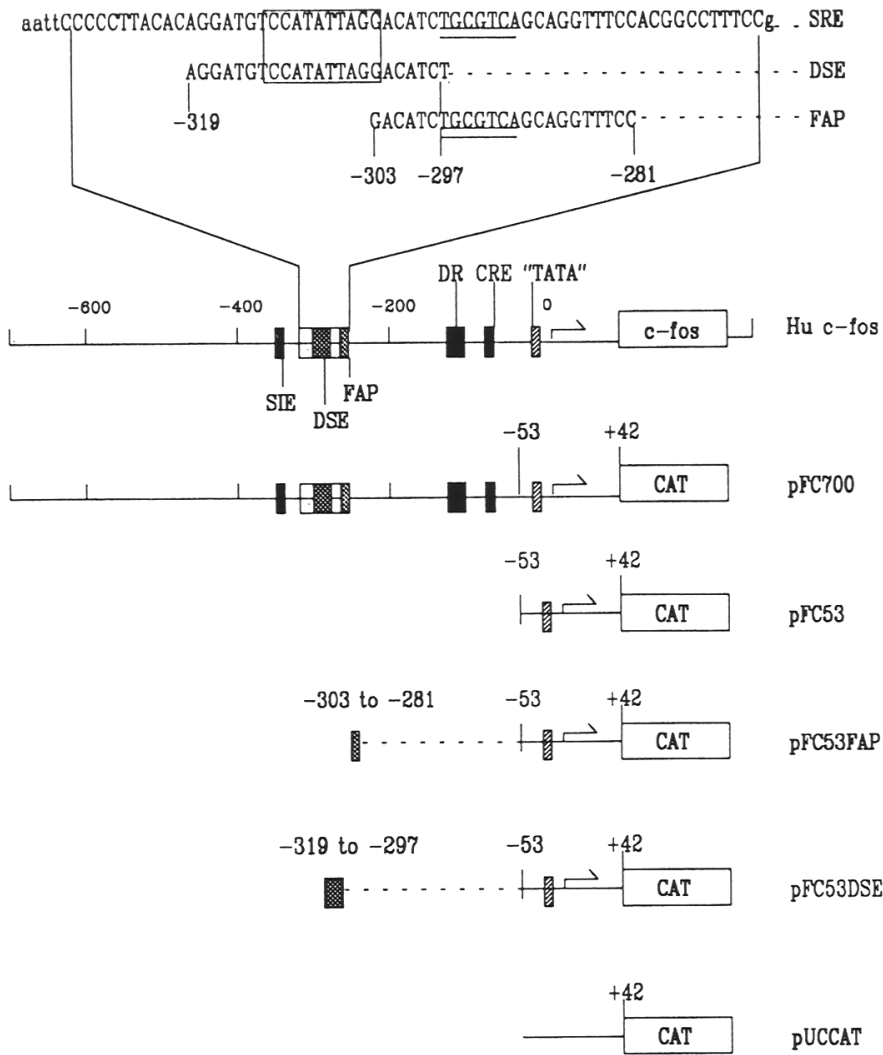

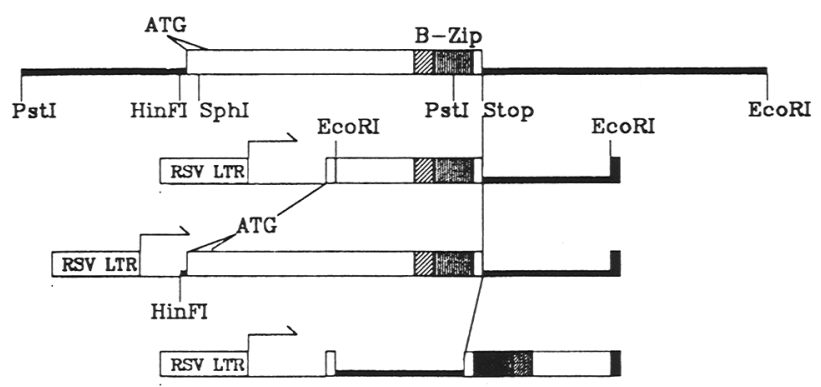

B
Figure 4. Activation of transcription through the DSE and FAP enhancers by recombinant rNFIL-6 expressed in vivo. (A) The structure of the fos-CAT reporter plasmids (generously donated by R. Prywes; Fisch et al. 1989b) and the various expression vectors are shown schematically. The rNFIL- 6 expression vectors contain the rNFIL- 6 cDNA insert from clone 21 in the sense (RSVArNFIL-6) or antisense [RSV $\Delta$ rNFIL-6|-1] orientation, or the complete coding region (RSVrNFIL-6). The construction of RSV $\Delta$ rNFIL- 6 and RSVrNFIL- 6 plasmids is described in detail in Materials and methods. Transfections were carried out in NIH 3T3 cells described in Materials and methods. CAT assays were performed according to Gorman et al. (1982) shown in B. The CAT assays from cell cotransfected with the reporter constructs PUCCAT (lanes 1,6,11), pFCFAP (lanes 2,7,12), pFCDSE (lanes 3,8,13), pFC53 (lanes 4,9,14), pFC700 (lanes 5,10,15); and the various illustrated expression vectors are shown RSVArNFIL6(-) (lanes 1-5), RSVrNFIL-6 (lanes 6-10), and RSVArNFIL-6 (lanes 11-15). The control RSV CAT expression vector is shown in lane 15. Quantitation of the CAT assays for each experiment was done by excising the acetylated $\left[{ }^{14} \mathrm{C}\right]$ chloramphenicol (the fastest-migrating spots) and the unmodified $\left[{ }^{14} \mathrm{C}\right]$ chloramphenicol (the slowestmigrating spot), and counting their ${ }^{14} \mathrm{C}$ levels in Aquasol in a liquid scintillation counter. Induction levels were calculated by comparing the relative amounts of acetylation (calculated as percent acetylaRSV $\triangle \mathrm{rNFIL}-6(-)$ tion) between the different experimental lanes.
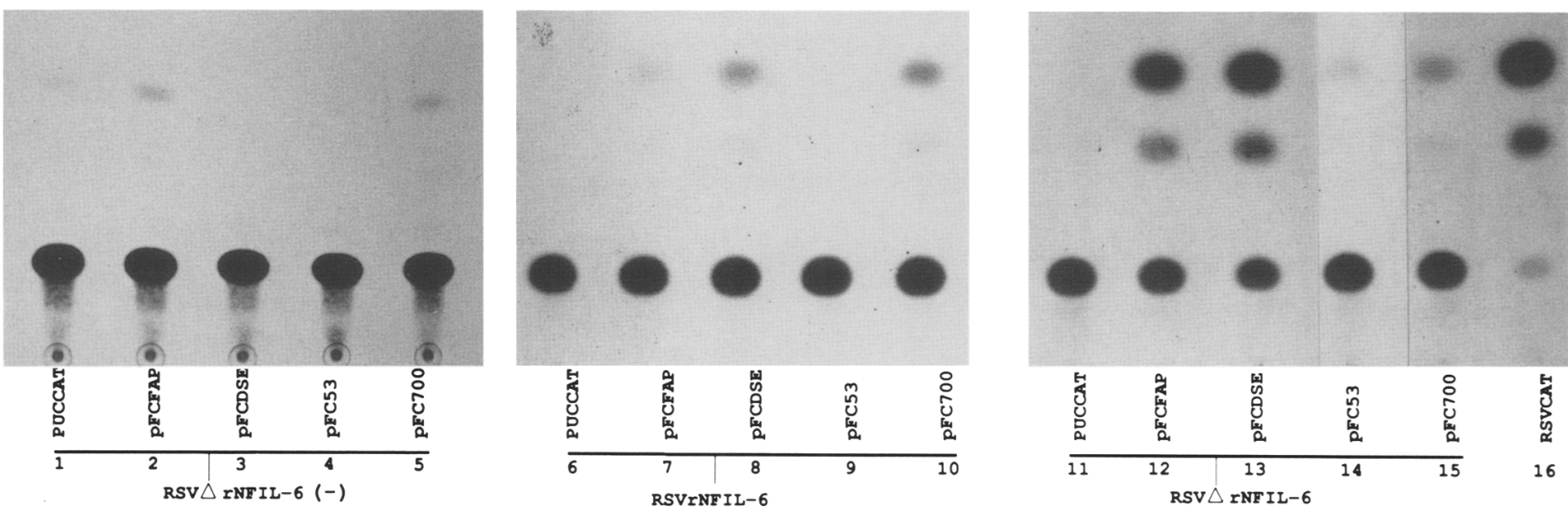
tein contains a polypeptide domain that renders the expressed product less active and requires cAMP-induced modification (not provided in this experiment) for full activity. Alternatively, because the nuclear localization of the protein expressed for the transfected plasmids is not known, the truncated polypeptide may be transported to the nucleus more effeciently than the wildtype rNFIL-6 protein (see below). The vector pFC700 with $700 \mathrm{bp}$ of the c-fos $5^{\prime}$-flanking region was activated only fivefold by RSVDrNFIL-6 (Fig. 4B, lanes 5,10,15). pFC700 might contain negative regulatory elements absent from the DSE and FAP oligonucleotide reporter constructs (Robbins et al. 1990). Alternatively, rNFIL-6 might act more efficiently when placed closer to the promoter. Although these results do not take into account possible modifications such as phosphorylation that may be required for full rNFIL- 6 activity, it is clear that in this assay rNFIL- 6 expression is capable of promoter activation through elements in the FAP and DSE oligonucleotides.

\section{The localization of rNFIL-6 in PC12 cells changes following stimulation with forskolin}

Because nucleoprotein-DNA complexes at the rNFIL- 6 site of the SRE are more abundant following forskolin treatment of PC12 cells, as shown in Figure 2B, we reasoned that either the affinity of rNFIL- 6 for DNA and/or its subcellular localization may be affected by cAMP. Therefore, we compared the cellular localization of rNFIL- 6 in untreated or forskolin-stimulated PC12 cells by immunofluorescence. As shown in Figure 5a, in unstimulated PC12 cells, antibodies specific to rNFIL-6 recognized an antigen dispersed throughout the cytoplasm with some nuclear reactivity. The localization of rNFIL-6 changed dramatically in PC12 cells following forskolin treatment. The dispersed pattern changed to one of predominantly nuclear staining as early as $30 \mathrm{~min}$ poststimulation (Fig. 5c), although the most intense nuclear staining was observed at $60 \mathrm{~min}$ after forskolin addition (Fig. 5e). The nuclear staining with the antirNFIL-6 antibody persisted for $2 \mathrm{hr}$ following stimulation (Fig. 5f), and even after $8 \mathrm{hr}$ some nuclear staining was detected (data not shown). This change in localization most likely reflects movement of rNFIL- 6 antigen rather than a change in background signal inasmuch as the reactivity of the antibody was blocked by rNFIL-6/ fusion peptide (Fig. 5b). Moreover, the relocalization of rNFIL- 6 is independent of new protein synthesis as forskolin treatment in the presence of cycloheximide still resulted in the movement of rNFIL-6 to the nucleus (Fig. 5d).

To provide an independent assessment of the change in localization of rNFIL- 6 following stimulation, we performed a Western blot analysis of fractionated cellular extracts of PC12 cells before and after forskolin treatment. The Western blot given in Figure 6 shows that rNFIL- 6 is present in the cytoplasm of unstimulated PC12 prior to treatment and that it is no longer detectable in the cytoplasm at 30 or $60 \mathrm{~min}$ following forskolin treatment [Fig. 6 (top), lanes 1-3], even after a longer exposure [Fig. 6 (bottom)]. During this interval the level of rNFIL- 6 in the nuclear fraction increases significantly (lanes 4-6). These data plus the fact that absolute levels of rNFIL-6 protein do not change following stimulation, as shown by Western analysis of whole cell protein in Figure 3A, suggest further that rNFIL-6 undergoes a cAMP-stimulated redistribution in the cell to the nucleus. It should be emphasized that these data cannot differentiate between an activated trans-location, because of the release of rNFIL- 6 from tethering in the cytoplasm and nuclear localization resulting from an increase in DNA-binding activity. Nevertheless, the kinetics of the cellular redistribution of rNFIL6 parallel the
Figure 5. rNFIL-6 localizes in the nucleus following forskolin treatment of PC12 cells. Phase and fluorescence microscopy were performed as described in Materials and methods. PC12 cells, which were untreated $(a)$ or treated for $30(c), 60(e)$, or $120(f) \mathrm{min}$ with forskolin $(10 \mu \mathrm{M})$, were fixed, permeabilized, and incubated with affinity-purified rabbit anti-rNFIL- 6 antibody followed by fluorescein-conjugated goat anti-rabbit IgG. In one experiment the antibody was first preabsorbed with trpE-rNFIL-6 fusion protein $(b)$, labeled $0^{\prime} \mathrm{Bk}$. In the experiment represented in $d\left(30^{\prime}+\mathrm{CHX}\right), \mathrm{PC} 12$ cells were treated with cycloheximide $30 \mathrm{~min}$ prior to a 30-min stimulation with forskolin.
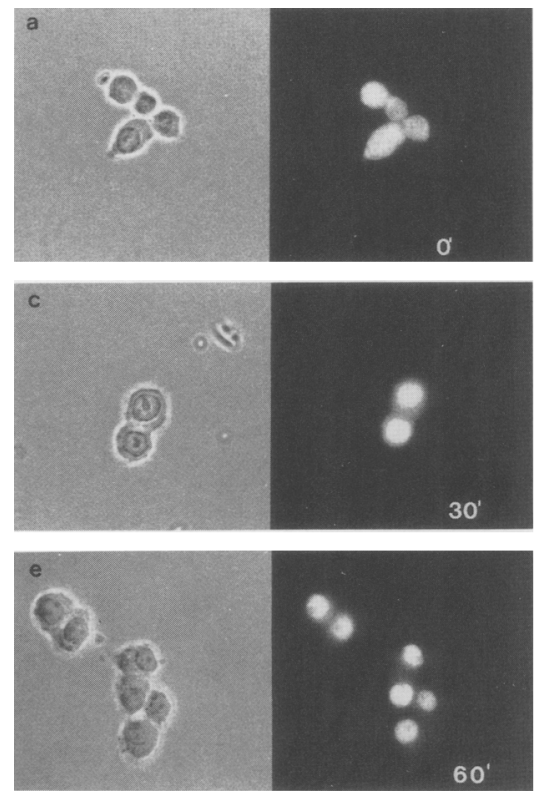
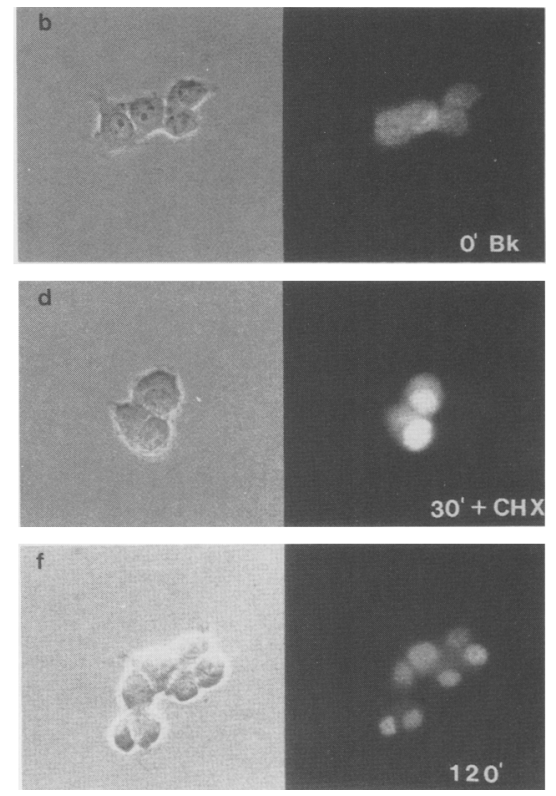


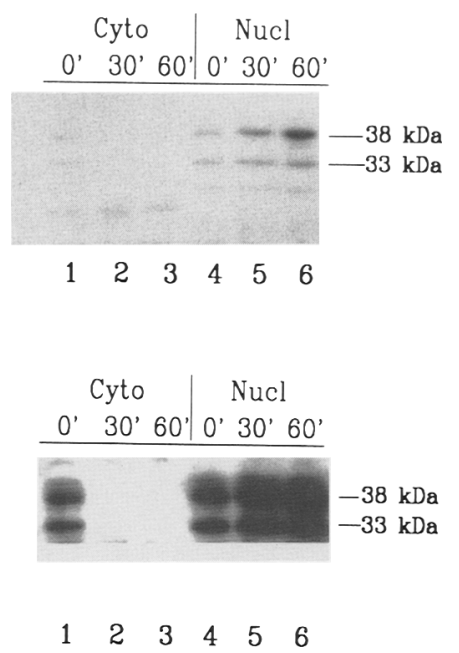

Figure 6. Western blot of cytoplasmic and nuclear fractions. Cytoplasmic (lanes 1-3) and nuclear (lanes 4-6) fractions were derived from PC12 cells directly or following treatment with forskolin for 30 or 60 min (lanes 1 and 4,2 and 5, 3 and 6, respectively|. Equal amounts of protein extracts were fractionated by SDS-PAGE on a $12 \%$ polyacrylamide gel, and transferred to nitrocellulose filter paper and subjected to Western blot analysis, as described in Materials and methods. The estimated sizes of the immunoreactive proteins (indicated) were estimated from prestained protein molecular mass size markers. Short ( $12 \mathrm{hr}$ ) and long ( 4 day) exposures are shown at top and bottom, respectively.

kinetics of increased phosphorylation of rNFIL-6 observed in PC12 cells following forskolin treatment. This raises the possibility that post-translational modification of rNFIL- 6 by phosphorylation may play a role in its prominent nuclear redistribution.

\section{Anti-rNFIL-6 recognizes a protein-DNA complex in HeLa nuclear extracts}

Velcich and Ziff (1990) have shown that a triplicated oligonucleotide, oligonucleotide $\mathrm{B}$, containing the FAP element and neighboring sequences including a partial but functional rNFIL-6-binding site (Metz and Ziff 1991), can confer cAMP inducibility and constitutive activity to a heterologous promoter when transfected into PC12 cells and HeLa cells, respectively. This differential activity in HeLa versus PC12 cells is not exclusively dependent on the core FAP sequence because oligonucleotides containing the consensus CRE or AP-1 site do not display the same activity as oligonucleotide $\mathrm{B}$. Because in vitro-synthesized rNFIL- 6 can bind oligonucleotide B but not oligonucleotides containing only the consensus AP1 or CRE sites (Metz and Ziff 1991), we reasoned that rNFIL- 6 binding may contribute to the additional regulatory features of oligonucleotide $B$.

To ascertain the existence and localization of the antirNFIL-6 reactive protein in HeLa cells, indirect immunofluorescence was performed on growing HeLa cells. Fluorescence was observed only in the nuclei of the cells
(Fig. 7), suggesting that HeLa anti-rNFIL-6 reactive protein may not be regulated in the same fashion as rNFIL- 6 in PC12 cells. Therefore, in the absence of a cAMP stimulus the anti-rNFIL- 6 reaction protein may be constitutively active in HeLa cells. This would be in agreement with the constitutive activity of oligonucleotide B, containing the FAP site (Velcich and Ziff 1990).

To determine whether rNFIL-6 or related DNA-binding activity is present in a HeLa nuclear extract, the ability of anti-rNFIL-6 antibody to disrupt an oligonucleotide B-specific protein-DNA complex derived from HeLa extract was analyzed. The FAP site contained in oligonucleotide B has been shown to interact with Fos/ Jun; therefore, the ability of anti-Fos and anti-Jun antibodies to disrupt the complex was also analyzed. In Figure 8, oligonucleotide B formed two specific complexes with HeLa nuclear extracts. Anti-rNFIL-6 disrupted complex I in lane 6, whereas anti-Jun, anti-Fos, and antirE12 (Metz and Ziff 1991) antibodies did not disrupt the complexes, as shown in lanes 2,3 , and 4 , respectively. A protein-DNA complex is also detected with oligonucleotide A. The formation of this complex is competed by the SRE oligonucleotide but not by oligonucleotides mutant for rNFIL-6 binding (data not shown). These data suggest that a factor related to rNFIL- 6 is present in HeLa extract and that this factor has the same binding specificity as rNFIL-6. A trpE-rNFIL-6 fusion peptide antigen blocked the disruption of the anti-rNFIL- 6 antibody in Figure 8 , lane 7 , confirming specificity of the antibody. It is important to note, however, that the specific complexes formed by oligonucleotide B may contain an additional factor, as the antibody failed to completely disrupt the protein-DNA complex. In addition, as indicated by the immunoprecipitation data, rNFIL- 6 is associated with at least two additional proteins.

\section{Discussion}

Several lines of evidence suggest that rNFIL- 6 functions directly in the cAMP-dependent activation of the SRE. These include the fact that rNFIL- 6 binds specifically to

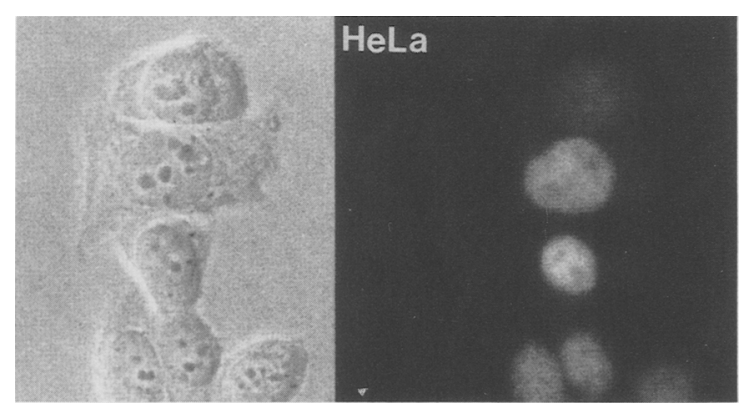

Figure 7. Antigen detected by anti-rNFIL-6 antibody in HeLa cells resides in the nucleus. Phase and fluorescence microscopy were performed as described in Materials and methods on cycling HeLa cells. 


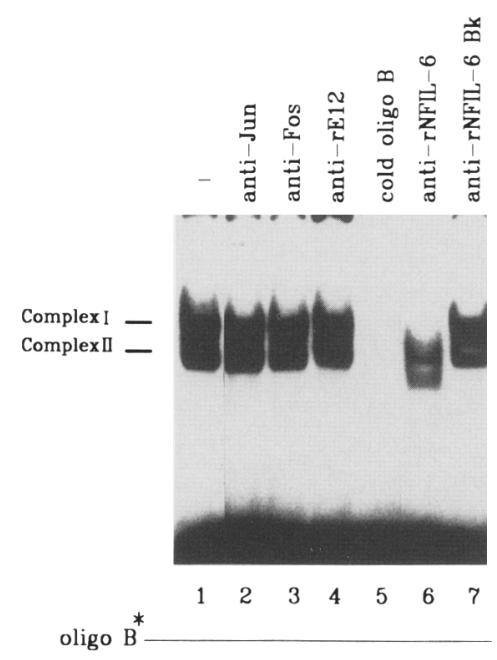

Figure 8. HeLa nucleoprotein complex binding the FAP oligonucleotide reacts with anti-rNFIL-6 antibody. Nuclear extracts $(15 \mu \mathrm{g})$ from HeLa cells were incubated for $30 \mathrm{~min}$ with the ${ }^{32} \mathrm{P}$-labeled oligonucleotide containing the FAP site in the absence or presence (lane 5) of a 100 molar (20 ng) excess of the unlabeled competitor oligonucleotide and analyzed on a $5 \%$ nondenaturing polyacrylamide gel, as described in Materials and methods. Nuclear extracts were incubated for $30 \mathrm{~min}$ at $0^{\circ} \mathrm{C}$ with $200 \mathrm{ng}$ of either affinity-purified anti-Jun (lane 2), anti-Fos (lane 3), anti-rE12 (lane 4), or anti-rNFIL-6 (lane 6) antibody, or anti-rNFIL- 6 antibody preabsorbed with an excess $(1 \mu \mathrm{g})$ of trpErNFIL-6 (lane 7) prior to DNA-binding reaction.

a site in the c-fos SRE (Metz and Ziff 1991) and that the level of such binding is higher in nuclear extracts from forskolin-treated $\mathrm{PC} 12$ cells than in nuclear extracts from untreated PC12 cells. rNFIL- 6 is phosphorylated and trans-locates to the nucleus following forskolin stimulation with kinetics that parallel transcriptional activation. Also, rNFIL- 6 is structurally related to C/EBP and NFIL-6 proteins, which are well established as transcription factors. rNFIL- 6 contains serine/threonine-rich and proline-rich regions also characteristic of transcription factors. Finally, the expression of rNFIL-6 from a plasmid will transcriptionally activate elements of the c-fos promoter that interact with rNFIL-6.

\section{Relationship to C/EBP}

rNFIL-6 recognizes an 8-nucleotide sequence overlapping the c-fos DSE, ATTAGGACAT (Metz and Ziff 1991), which is identical to the C/EBP-binding site of the liver-specific gene transthyretin. Despite the similarity of the b-zip domains of C/EBP and rNFIL-6, the amino acid sequences outside this region diverge greatly. This suggests that rNFIL-6 is functionally distinct from C/EBP. C/EBP has been proposed to be the factor that regulates liver- and fat-specific genes requiring CCAAT enhancer elements and is thought to function in energy metabolism and to regulate genes in response to changes in the levels of specific hormones, including glucagon, which operates through a cAMP-activated pathway (for review, see McKnight et al. 1989|. C/EBP-binding sites have been suggested to mediate cAMP control of the albumin and 442(aP2) genes (Christy et al. 1989; Herrera et al. 1989; McKnight et al. 1989|. Recently, Park et al. (1990) reported that a CAMP-responsive CRE site in the phosphoenolpyruvate carboxykinase gene can bind C/EBP. However, a direct role for C/EBP in CAMP induction at these sites has not been demonstrated. rNFIL-6, which can be activated by cAMP-dependent pathways, is, like C/EBP (Birkenmeier et al. 1989), expressed in the liver and binds to CCAATT enhancer elements (R. Metz and E. Ziff, in press). These properties raise the possibility that rNFIL- 6 plays an important role in regulation of liver-specific genes responding to CAMP, now attributed to C/EBP. NFIL-6 has been shown to activate certain liver-specific genes in response to IL-6 treatment (Poli et al. 1990).

\section{rNFIL-6 recognizes and trans-activates a CCAATT enhancer element in the $c$-fos $S R E$}

rNFIL-6 recognizes the CCAATT enhancer element within the DSE. It also binds oligonucleotide B, containing the FAP site in vitro, albeit with reduced affinity relative to binding the SRE (Metz and Ziff 1991). This binding might not be anticipated because oligonucleotide B contains only half of the rNFIL- 6 site. The transcription factor CREB has been shown to bind half-sites (Yamamoto et al. 1988); therefore, possibly rNFIL-6 is also capable of binding to a half-site present within oligonucleotide B. Alternatively, the sequence recognition by rNFIL- 6 may be very broad, as was found for C/EBP (Park et al. 1990).

Transcription of the c-fos gene peaks $1 \mathrm{hr}$ following cAMP stimulation in PC12 cells (Greenberg et al. 1985). Both the DSE and the FAP oligonucleotides function independently as CREs (Fisch et al. 1989b; Velcich and Ziff 1990); thus, the binding of rNFIL-6 to both of these oligonucleotides may provide the target for cAMP-generated signals.

Treatment of $\mathrm{PCl} 2$ cells with forskolin increases the level of a specific protein-DNA complex formed by nuclear extracts with the rNFIL- 6 site. This suggests that the formation of the complex is inducible by cAMP. Because an antibody generated against a trpE-rNFIL- 6 fusion protein disrupts the complex, we conclude that this complex, complex II, contains rNFIL-6. In support of this, our antibody in immunoprecipitation and Western blot analysis of $\mathrm{PCl} 2$ extracts recognizes only two protein species, the 33- and 38-kD peptides, which are products of the single rNFIL- 6 mRNA. Moreover, in vivo expression of either rNFIL- 6 or $\triangle$ rNFIL- 6 activates the reporter constructs $\mathrm{pFCDSE}$ and pFCFAP, which are under the control of the DSE oligonucleotide and oligonucleotide B, respectively. $\triangle$ rNFIL- 6 expression also trans-activates a c-fos promoter plasmid that retains extensive 5 '-flanking sequence (pFC700); however, to a lesser extent than for pFCFAP and pFCDSE. Possibly rNFIL-6 functions more efficiently when its binding sequence is positioned close to the TATA element and the transcrip- 
tion initiation site. Alternatively the complete 5 '-flanking region of $\mathrm{c}$-fos may contain negative regulatory sites that reduce the effectiveness of rNFIL-6. Interestingly, our transient assays show that the complete rNFIL- 6 protein is a less effective trans-activator than the truncated rNFIL- 6 product, $\Delta$ rNFIL- 6 protein. This may be because of the lower expression of the complete rNFIL-6. However, we note that these trans-activation studies were performed in the absence of cAMP stimulation. Therefore, it is also possible that the complete rNFIL-6 protein requires cAMP-dependent post-translational modification for its full activation while $\Delta$ rNFIL-6 is constitutively active.

\section{rNFIL-6 is a phosphoprotein}

The anti-rNFIL- 6 antibody recognizes two protein species of 33 and $38 \mathrm{kD}$. The relationship of the 33- and $38-\mathrm{kD}$ proteins is currently under investigation. However, their sizes are consistent with the translation of both products from the same rNFIL-6 message and initiation of translation at either of the first two AUG codons. In support, in vitro translation of the complete rNFIL- 6 mRNA yields two products of $\sim 33$ and $38 \mathrm{kD}$ (R. Metz and E. Ziff, unpubl.). Both 33- and 38-kD polypeptides become phosphorylated in PC12 cells following forskolin treatment. Because all reported cellular effects of cAMP require the catalytic subunit of cAPK, C-cAPK (for review, see Montminy et al. 1989), rNFIL-6 may also be activated by C-cAPK. However, we have no direct evidence demonstrating that rNFIL- 6 is directly phosphorylated by C-cAPK. The rNFIL- 6 structure contains the sequence KPSKKPS located between amino acids 98 and 106, which may provide a phosphorylation site for cAPK. A similar motif, RRPS, is required for the C-cAPK-dependent (Gonzalez et al. 1989; Yamamoto et al. 1990) and CaM-dependent activation of CREB (Sheng et al. 1991).

rNFIL-6 is associated with 43- and $64-k D$ proteins and is phosphorylated by a cAMP-regulated protein kinase

Following forskolin treatment, rNFIL- 6 is associated with two proteins, a $43-\mathrm{kD}$ phosphoprotein, $\mathrm{p} 43$, and a $64-\mathrm{kD}$ protein, $\mathrm{p} 64$, the latter detected by $\left.{ }^{35} \mathrm{~S}\right]$ methionine labeling. The $43-\mathrm{kD}$ phosphoprotein is not detected in the ${ }^{35}$ S-labeled extracts, possibly because p43 is not synthesized at appreciable levels during the labeling period. It is not possible from these experiments to determine whether CAMP induces the association of rNFIL-6 with p43 and rNFIL- 6 with p64 or, alternatively, the phosphorylation of $\mathrm{p} 43$ and the synthesis of $\mathrm{p} 64$. These experiments also fail to address the nature of the interactions between rNFIL- 6 and p43 and p 64 or the stoichiometry of their associations. However, it is intriguing to speculate that the complexes between rNFIL- 6 and p43 and p64, like the interaction of c-Fos with c-Jun, may modulate binding of rNFIL- 6 to DNA and/or affect its ability to stimulate transcription through the c-fos SRE.

In the cell, rNFIL- 6 may cooperate with other protein factors interacting with the DSE or FAP sequences. We note that a CCAATT site in the adipocyte $\mathrm{p} 2$ gene has been reported to affect the activity of an adjacent AP-1 site (Christy et al. 1989; Herrera et al. 1989). Similarly, in the IL- 6 gene, a CCAAT-enhancer site that responds to IL-1 and IL-6 lies immediately adjacent to a CRE consensus sequence, at a position identical to that of the rNFIL-6 site with respect to the adjacent FAP core sequences in the c-fos promoter (Akira et al. 1990; Isshiki et al. 1990). The similarity of arrangement of these independent enhancer transcriptional elements suggests functional significance. Because of the modular nature of many enhancer elements (for review, see Dynan 1989), rNFIL-6 site activity may also be influenced by transcription factors binding at the neighboring AP-1-like and DSE sites. It has not yet been determined whether rNFIL- 6 can independently provide a cAMP response in the absence of the neighboring sites. However, the DSE and FAP oligonucleotides, which bind rNFIL- 6 , are each independently cAMP responsive (Fisch et al. 1989b; Siegfried and Ziff 1990; Velcich and Ziff 1990; R. Metz and E. Ziff, unpubl.). Possibly rNFIL- 6 modulates the activity of the factors binding the AP-1-like or DSE sites. A similar mechanism has been described for the transcription factor AP-2 (Hyman et al. 1989).

\section{rNFIL-6 trans-locates to the nucleus in PC12 cells following forskolin treatment}

The molecular mechanism for the apparent increase in the amount of rNFIL-6 DNA-binding activity in PC12 nuclear extracts following forskolin treatment is not known. Indirect immunofluorescence microscopy shows that antigens recognized by anti-rNFIL- 6 antibody are present in both the cytoplasm and nucleus of $\mathrm{PC} 12$ cells before stimulation. This pattern of fluorescence changes upon induction with forskolin, whereupon the staining becomes predominately nuclear. The apparent relocalization of rNFIL- 6 was corroborated by Western analysis of cytoplasmic and nuclear extracts from untreated and foskolin-stimulated $\mathrm{PC} 12$ cells. This also showed that rNFIL- 6 is present in the cytoplasm prior to stimulation but is undetectable in this compartment following stimulation. Because the steady-state levels of rNFIL-6 do not change in whole-cell extracts following forskolin treatment and Western analysis demonstrates a marked increase in rNFIL- 6 in nuclear fractions, we conclude that rNFIL- 6 accumulates in the nucleus. We cannot determine from our data whether the nuclear localization of rNFIL- 6 is a process caused by its regulated release from cytoplasmic anchoring, like NF-кB (Baeuerle and Baltimore 1988), or whether an increase in its DNA-binding activity allows more molecules to be tethered in the nucleus. Alternatively, the nuclear localization signal may be unmasked following stimulation. The time course of nuclear localization is in accord with the kinetics of rNFIL-6 phosphorylation following forskolin treatment. Both phosphorylation and nuclear accumulation peak at $1 \mathrm{hr}$ following forskolin treatment. These data suggest a model in which the nuclear trans-location of rNFIL- 6 is 
dependent on an event controlled by cAMP-dependent phosphorylation. The ability of rNFIL- 6 to bind and trans-activate the SRE of c-fos suggests that rNFIL- 6 is involved in the regulation of c-fos transcriptional activity through a cAMP-regulated pathway.

Anti-rNFIL-6 reacts with a HeLa nucleoprotein that recognizes oligonucleotide $\mathrm{B}$. Unlike the case of $\mathrm{PC} 12$ cells, the HeLa NFIL-6-like factor is nuclear under all conditions tested. These data are consistent with the constitutive enhancer activity observed with the triplicated oligonucleotide B, containing the FAP site, in HeLa cells and in v-raf-transformed NIH 3T3 fibroblasts (Siegfried and Ziff 1990). These data suggest that rNFIL-6 belongs to a group of factors, possibly a subgroup of the C/EBP gene family, which are distinguished by their differential cell type expression or activation by cell transformation.

\section{Materials and methods}

Oligonucleotide synthesis

Oligonucleotides were synthesized by B. Goldschmitt with an Applied Biosystems oligonucleotide synthesizer and were purified by electrophoresis on an $8 \mathrm{~m}$ urea/ $8 \%$ polyacrylamide gel. Complementary oligonucleotides were then mixed in equal molar amounts and annealed in annealing buffer $[10 \mathrm{~mm}$ Tris $(\mathrm{pH}$ 8.0 ), $150 \mathrm{~mm} \mathrm{NaCl} \mathrm{MgCl}_{2}, 1 \mathrm{~mm}$ spermine] by heating to $88^{\circ} \mathrm{C}$ for $2 \mathrm{~min}$, followed by heating at $68^{\circ} \mathrm{C}$ and $37^{\circ} \mathrm{C}$ for $15 \mathrm{~min}$. The FAP (oligonucleotide $\mathrm{B}$ ) and DSE oligonucleotides were described previously (Metz et al. 1988; Siegfried et al. 1990).

\section{Cell culture and stimulations}

PC12 cells were maintained in Dulbecco's modified Eagle medium (DMEM) containing 10\% defined and supplemented calf serum, $5 \%$ equine serum (Hyclone Laboratories, Sterile Systems, Inc., Logan, UT), $10 \mathrm{~mm}$ glutamine, and $0.02 \%$ penicillin/ streptomycin, in a humidified $37^{\circ} \mathrm{C}$ incubator with $10 \% \mathrm{CO}_{2}$ atmosphere. Cells were plated on plastic culture dishes coated with collagen (Collagen Corporation, Palo Alto, CA) at a density of $\sim 3 \times 10^{6}$ cells $/ 10-\mathrm{cm}$ dish. When noted, PC12 cells were stimulated with nerve growth factor (NGF) $(50 \mathrm{ng} / \mathrm{ml}$; provided by Dr. Robert Stack, Univeresity of Michigan, Flint) in fresh media. NIH 3 T3 and HeLa cells were grown in $10 \%$ and $5 \%$ calf serum (GIBCO), respectively. PC12 and 3T3 cells, when noted, were stimulated with $10 \mu \mathrm{M}$ forskolin (Sigma) supplied in fresh medium.

\section{Nuclear extracts and DNA mobility-shift assay}

PC12 nuclear extracts were prepared from untreated or stimulated cell cultures, essentially as described by Dignam et al. (1983), and dialyzed against BCl00/D/P buffer [20 mM HEPES (pH 7.9), $0.1 \mathrm{M} \mathrm{KCl}, 0.2 \mathrm{mM}$ EDTA, 20\% glycerol, $0.5 \mathrm{~mm}$ PMSF (Sigma), $0.5 \mathrm{~mm}$ dithiothreitol, and $10 \mathrm{~mm} \mathrm{NaF}$ ] at $4^{\circ} \mathrm{C}$, aliquoted, and frozen at $-70^{\circ} \mathrm{C}$. Protein concentrations were determined with the Bio-Rad protein assay kit (Richmond, CA).

For DNA-protein binding, reactions were carried out as described previously (Metz and Ziff 1991). Inhibition of proteinDNA complex formation with affinity-purified anti-rNFIL- 6 antibody was performed by preincubating nuclear extract with an appropriate amount of antibody $15 \mu \mathrm{g}$ of extract : $100 \mathrm{ng}$ antibody) for $30 \mathrm{~min}$ at $0^{\circ} \mathrm{C}$, prior to its addition to the DNA reac- tion mixture. Preincubation of the antibody with trpE-rNFIL-6, trpE-C/EBP, or trpE was carried out at $4^{\circ} \mathrm{C}$ for $60 \mathrm{~min}$ prior to the incubation of the antibody with nuclear extract.

\section{Plasmid construction}

RSVArNFIL- 6 |+ 1, RSV $\Delta$ rNFIL-6 - - , and RSVrNFIL-6 were constructed by cloning the HindIII-BamHI inserts of T7 $\Delta$ rNFIL$6 \mid+1$, T7 rNFIL-6|-1, and T7rNFIL-6 (described in Metz and Ziff 1991), respectively, into the vector portion of HindIIIBamHI-digested RSV CAT (Gorman et al. 1982). pFCFAP, pFCDSE, pFC53, pFC700, and PUCCAT (pFC53A, pFC53E, pFC700, and PUCCAT, respectively; Fisch et al. 1989b/ were generously provided by Ron Prywes.

\section{Western blot analysis}

Whole-cell or nuclear and cytoplasmic fractions were prepared as described (Bunce et al. 1988). Extracts were fractionated by SDS-PAGE (12\%) (Laemmli 1970) and were assayed by Western analysis as described in Gizang-Ginsberg and Ziff (1990). AntirNFIL- 6 antibody was diluted $1: 1000$. Immunoreactive peptides were detected by ${ }^{125}$ I-labeled protein A (New England Nuclear).

\section{Immunofluorescence}

For immunofluorescence, cells were grown on 10 -mm glass circular cover slides in 24-well microtiter dishes under the same conditions as described above. For PC12 cells, the cover slides were first coated with collagen (as described above). The cells were washed three times with isotonic PBS, fixed by adding $20^{\circ} \mathrm{C}$ methanol to each well, and incubated at $-20^{\circ} \mathrm{C}$ for 20 $\mathrm{min}$. The fixed cells were rehydrated slowly in ice-cold PBS. The coverslips were then layered with an appropriate dilution (1: 500) of primary antibody in TBST [50 mM Tris ( $\mathrm{pH} 7.5$ ), 150 $\mathrm{mM} \mathrm{NaCl}, 0.05 \%$ Tween, and 3\% BSA (fraction V)] and incubated at $37^{\circ} \mathrm{C}$ for $1 \mathrm{hr}$. Following three washes in PBS the cells were layered with the appropriate dilution $(1: 250)$ of secondary antibody (fluorescein-conjugated goat anti-rabbit antibody) in TBST at $37^{\circ} \mathrm{C}$ for $45 \mathrm{~min}$. This was followed by three PBS washes and mounting with immunomount. Cells were then examined by fluoromicroscopy.

\section{Immunoprecipitation}

PC12 cells were cultured as described above. Cells were grown in 35-mm dishes and placed in DMEM lacking methionine, for $\left.{ }^{32} \mathrm{~S}\right]$ methionine labeling, or DMEM without phosphate, for $\left[{ }^{32} \mathrm{P}\right.$ ]orthophosphate labeling, $15 \mathrm{~min}$ (for ${ }^{35} \mathrm{~S}$ ) or $2 \mathrm{hr}$ (for ${ }^{32} \mathrm{P}$ ) prior to the addition of the label. Prior to harvesting, $1 \mathrm{mCi}$ of $\left.{ }^{[5} \mathrm{S}\right]$ methionine in $0.4 \mathrm{ml}$ of DMEM without methionine plus $10 \%$ dialyzed calf serum was added to the culture for $4 \mathrm{hr}$. Where noted, during the labeling period the cells were stimulated for the indicated times with $10 \mu \mathrm{M}$ forskolin. For ${ }^{32} \mathrm{P}$ labeling, cells were incubated with $\left[{ }^{32} \mathrm{P}\right]$ orthophosphate $(0.5$ $\mathrm{mCi}$ ) for $4 \mathrm{hr}$ prior to harvesting. During this period the cells were stimulated with $10 \mu \mathrm{M}$ forskolin for designated times.

Immunoprecipitations were carried out on cellular extracts prepared from labeled cells, as described previously (Vosatka et al. 1989). In some experiments the lysates were denatured by boiling for $5 \mathrm{~min}$ prior to immunoprecipitation. In the blocking experiments, the antibody was preabsorbed with a 100 molar excess of its trpE- $\Delta$ rNFIL- 6 or trpE-C/EBP fusion proteins for $30 \mathrm{~min}$ prior to its addition to the lysate. The immunoprecipitated proteins were analyzed by $12 \%$ SDS-PAGE with prestained protein molecular mass size markers. The gel was then 
treated with Enhance (New England Nuclear) (except ${ }^{32} \mathrm{P}$-containing gels), dried, and examined by autoradiography.

\section{Transient cell transfections and CAT assay}

Transfection of NIH 3T3 cells with plasmids was by the calcium phosphate precipitation procedure as described previously (Velcich and Ziff 1985). Five micrograms of RSV expression plasmid and $10 \mu \mathrm{g}$ of reporter plasmid were used to cotransfect $1 \times 10^{6}$ cells. The cells were placed in fresh media after $12 \mathrm{hr}$ and harvested $24 \mathrm{hr}$ later. Cell extracts were prepared and analyzed for CAT activity as described by Gorman et al. (1982).

\section{Acknowledgments}

This work was supported by grants MV75 from the American Cancer Society and CA44042 from the National Cancer Institute. We thank George Prendergast and Karen Buchkovich for a critical review of the manuscript. E.Z. is an investigator of the Howard Hughes Medical Institute. R.M. was supported by training grant 5T32CA09161 to the New York University (NYU) Medical Center Pathology Department and by grant 2P50MH35976 to the NYU Medical Health Clinical Research Center.

The publication costs of this article were defrayed in part by payment of page charges. This article must therefore be hereby marked "advertisement" in accordance with 18 USC section 1734 solely to indicate this fact.

\section{References}

Akira, S., H. Isshiki, T. Sugita, O. Yanabe, S. Konoshita, Y. Nishio, T. Nakajima, T. Hirano, and T. Kishimoto. 1990. A nuclear factor for IL-6 expression (NF-IL6) is a member of a C/EBP family. EMBO I. 9: 1897-1906.

Almendral, J.M., D. Sommer, H. MacDonald-Bravo, J. Buckardt, J. Perera, and R. Bravo. 1988. Complexity of the early genetic response to growth factors in mouse fibroblast. Mol. Cell. Biol. 8: $2140-2148$.

Baeuerle, P.A. and D. Baltimore. 1988. Activation of DNA-binding activity in an apparently cytoplasmic precursor of the NF-кB transcription factor. Cell 53: 211-217.

Birkenmeier, E.H., B. Gwynn, S. Howard, J. Jerry, J.I. Gordon, W.H. Landschulz, and S.L. McKnight. 1989. Tissue-specific expression, developmental regulation, and genetic mapping of the gene encoding CCAATT/enhancer binding protein. Genes \& Dev. 3: 1146-1156.

Boxer, L.M., R. Prywes, R.G. Roeder, and L. Kedes. 1989. The sarcomeric actin CArG-binding factor is indistinguishable from the c-fos serum response factor. Mol. Cell. Biol. 9: 515522.

Bunce, C.M., J.A. Thiek, J.M. Lord, D. Mills, and G. Brown. 1988. A rapid procedure for isolating hemopoietic cell $\mathrm{nu}$ clei. Ann. Biochem. 175: 67-73.

Chang, C.J., T.T. Chen, H.Y. Lei, D.S. Chen, and S.C. Lee 1990. Molecular cloning of a transcription factor, AGP/EBP, that belongs to members of the C/EBP family. Mol. Cell. Biol. 10: 6642-6653.

Chavrier, P., U. Janssen-Timmen, M. Mattei, M. Zerial, R. Bravo, and P. Charnay. 1989. Structure, chromosomal location, and expression of the mouse zinc finger gene krox-20: Multiple gene products and coregulation with the proto-oncogene c-fos. Mol. Cell. Biol. 9: 787-797.

Christy, B.A. and D. Nathans. 1989. Functional serum response elements upstream of the growth factor-induced gene zif 268 . Mol. Cell. Biol. 9: 4889-4895.

Christy, R.J., V.W. Yang, J.M. Ntambi, D.E. Geiman, W.H.
Landschulz, A.D. Friedman, Y. Nakabeppu, T.J. Kelly, and W.D. Lane. 1989. Differentiation-induced gene expression in 3T3-L1 preadipocytes: CCAAT/enhancer binding protein interacts with and activates the promoters of two adipocytespecific genes. Genes \& Dev. 3: 1323-1335.

Costa, R.H., D.R. Grayson, K.G. Xanthopoulos, and J.E. Darnell, Jr. 1988. A liver-specific DNA binding protein recognizes multiple nucleotide sites in regulatory regions of transthyretin, $a$-1-antritrypsin, albumin, and SV40 genes. Proc. Natl. Acad. Sci. 85: 3840-3844.

Curran, T. 1988. fos. In The oncogene handbook (ed. E.P. Reddy, A.M. Skalka, and T. Curran), pp. 305-325. Elsevier, Amsterdam.

Descombes, P., M. Chojkier, E. Lichtsteiner, E. Falvey, and U. Schibler. 1990. LAP, a novel member of the C/EBP gene family, encodes a liver-enriched transcriptional activator protein. Genes \& Dev. 3: 1541-1551.

Dignam, J.D., R.M. Lebowitz, and R.G. Roeder. 1983. Accurate transcription initiation by RNA polymerase II in a soluble extract from isolated mammalian nuclei. Nucleic Acids Res. 11: $1475-1489$.

Dynan, W.S. 1989. Modularity in promoter and enhancers. Cell 58: $1-4$

Fisch, T.M., R. Prywes, and R.G. Roeder. 1987. c-fos sequences necessary for basal expression and induction by epidermal growth factor, 12-O-tetradecanoyl phorbol-13-acetate, and calcium ionophore. Mol. Cell. Biol. 7: 3490-3502.

- 1989a. An AP-1 binding site in the c-fos gene can mediate induction by epidermal growth factor and 12-O-tetradecanoyl phorbol-13-acetate. Mol. Cell. Biol. 9: 13271331.

Fisch, T.M., R. Prywes, M. Celeste Simon, and R.G. Roeder. 1989b. Multiple sequence elements on the c-fos promoter mediate induction by cAMP. Genes \& Dev. 3: 198-211.

Gilman, M.Z. 1988. The c-fos serum response element responds to protein kinase C-dependent and -independent signals but not to cyclic AMP. Genes \& Dev. 2: 394-402.

Gilman, M.Z., R.N. Wilson, and R.A. Weinberg. 1986. Multiple protein-binding sites in the $5^{\prime}$-flanking region regulate $\mathrm{c}$-fos expression. Mol. Cell. Biol. 6: 4305-4316.

Gizang-Ginsberg, E. and E.B. Ziff. 1990. Nerve growth factor regulates tyrosine hydroxylase gene transcription through a nucleoprotein complex that contains c-fos. Genes \& Dev. 4: $477-491$.

Gonzalez, G.A. and M.R. Montminy. 1989. Cyclic AMP stimulates somatostatin gene transcription by phosphorylation of CREB at serine-133. Cell 59: 657-680.

Gorman, C.M., L.F. Moffat, and B.H. Howard. 1982. Recombinant genomes which express chloramphenicol acetyltransferase in mammalian cells. Mol. Cell. Biol. 2: 1044-1051.

Graham, R. and M. Gilman. 1991. Distinct protein targets for signals acting at the c-fos serum response element. Science 251: 189-192.

Greenberg, M.E. and E.B. Ziff. 1984. Stimulation of 3T3 cells induces transcription of the c-fos proto-oncogene. Nature 311: 433-438.

Greenberg, M.E., L.A. Greene, and E.B. Ziff. 1985. Nerve growth factor and epidermal growth factor induce rapid transient changes in proto-oncogene transcription in PC-12 cells. $/$. Biol. Chem. 26: 14101-14110.

Greenberg, M.E., Z. Siegfried, and E.B. Ziff. 1987. Mutation of the c-fos gene dyad symmetry element inhibits serum inducibility of transcription in vivo and the nuclear regulatory factor binding in vitro. Mol. Cell. Biol. 7: 1217-1225.

Herrera, R.O., H.S. Robinson, K.G. Xanthopulos, and B.M. Spiegelman. 1989. A direct role for $\mathrm{C} / \mathrm{EBP}$ and AP-1-binding 
site in gene expression linked to adipocyte differentiation. Mol. Cell. Biol. 9: 5331-5339.

Hyman, S.E., M. Comb, Y. Lin, J. Pearlberg, M.R. Green, and H.M. Goodman. 1988. A common trans-acting factor is involved in transcription regulation of neurotransmitter genes by cyclic AMP. Mol. Cell. Biol. 8: 4225-4233.

Hyman, S.E., M. Comb, J. Pearlberg, and H.M. Goodman. 1989. An AP-2 element acts synergistically with the cyclic AMPand phorbol ester-inducible enhancer of the human proenkephalin gene. Mol. Cell. Biol. 9: 321-324.

Isshiki, H., S. Akira, O. Tanabe, T. Nakajima, T. Shimaamoto, T. Hirano, and T. Kishimoto. 1990. Constitutive and interleukin-1 (IL-1)-inducible factors interact with the IL-1-response element in the IL-6 gene. Mol. Cell. Biol. 10: 27572764.

Laemmli, U.D. 1970. Cleavage of structural proteins during the assembly of the head of bacteriophage T4. Nature 227: 680684.

Lee, W., P. Mitchell, and R. Tjian. 1987. Purified transcription factor AP-1 interacts with TPA-inducible enhancer elements. Cell 49: 741-752.

McKnight, S.L., D.L. Lane, and Gluecksohn-Waelsch. 1989. Is CCAAT/enhancer binding protein central regulator of energy metabolism? Genes \& Dev. 3: 2021-2024.

Metz, R. and E. Ziff 1991. The helix-loop-helix protein $\mathrm{rE} 12$ and the C/EBP-related factor INFIL-6 bind to neighboring sites within the c-fos serum response element. Oncogene (in press).

Metz, R., J. Gorham, Z. Siegfried, D. Leonard, E. Gizang-Ginsberg, M.A. Thompson, D. Lawe, T. Kouzarides, R. Vosatka, D. MacGregor, S. Jamal, M.E. Greenberg, and E.B. Ziff. 1988. Gene regulation by growth factors. Cold Spring Harbor Symp. Quant. Biol. 52: 727-737.

Minty, A. and L. Kedes. 1986. Upstream regions of the human cardiac actin gene that modulate its transcription in muscle cells: Presence of an evolutionarily conserved repeated motif. Mol. Cell. Biol. 6: 2125-2136.

Mohun, T., N. Garrett, and R. Treisman. 1987. Xenopus cytoskeletal actin and human c-fos gene promoters share a conserved protein binding site. EMBO J. 6: 667-673.

Montminy, M.R. and L.M. Bilezikjan. 1987. Binding of a nuclear protein to the cyclic AMP response element of the somatostatin gene. Nature 328: 175-178.

Montminy, M.R., K.A. Sevarino, J.A. Wagner, G. Mandel, and R.H. Goodman. 1986. Identification of a cyclic-AMP-responsive element within the rat somatostatin gene. Proc. Natl. Acad. Sci. 83: 6682-6686.

Norman, C., M. Runswick, R. Pollock, and R. Treisman. 1988. Isolation and properties of cDNA clones encoding SRF, a transcription factor that binds to the c-fos serum response element. Cell 55: 989-1003.

Park, E.A., W.J. Roesler, J. Liu, D.J. Klemm, A.L. Gourney, J.D. Thatcher, J. Shuman, A. Friedman, and R.W. Hanson. 1990. The role of the CCAAT/enhancer-binding protein in the transcriptional regulation of the gene for phosphoenolpyruvate carboxykinase (GTP). Mol. Cell. Biol. 10: 6264-6272.

Poli, V., F.P. Mancini, and R. Cortese. 1990. IL-6DBP, a nuclear protein involved in interleukin- 6 signal transduction, defines a new family of leucine zipper proteins related to C/EBP. Cell 63: 643-653.

Prywes, R. and R.G. Roeder. 1987. Purification of the c-fos enhancer-binding protein. Mol. Cell. Biol. 7: 3482-3489.

Rivera, V.M., M. Sheng, and M.E. Greenberg. 1990. The inner core of the serum response element mediates both the rapid induction and subsequent repression of c-fos transcription following serum stimulation. Genes \& Dev. 4: 255-268.
Robbins, P.D., J.M. Horowitz, and R.C. Mulligan. 1990. Negative regulation of human c-fos expression by the retinoblastoma gene product. Nature 346: 668-671.

Ryan, W.A., Jr., B.R. Franza Jr., and M.Z. Gilman. 1989. Two distinct cellular phosphoproteins bind to the c-fos serum response element. EMBO I. 8: 1785-1792.

Sassone-Corsi, P., J. Visvader, L. Ferland, P.L. Mellon, and I.M. Verma. 1988a. Induction of the proto-oncogene fos transcription through the adenylate cyclase pathway: Characterization of a cAMP-responsive element. Genes \& Dev. 2: 15291538.

Sassone-Corsi, P., J.C. Sisson, and I.M. Verma. 1988b. Transcriptional autoregulation of the proto-oncogene fos. Nature 334: 314-319.

Schröter, H., P.E. Shaw, and A. Nordheim. 1987. Purification of intercalator-released $\mathrm{p} 67$, a polypeptide that interacts specifically with the c-fos serum response element. Nucleic Acids Res. 15: 10145-10158.

Schröter, H., C.G. Mueller, K. Meese, and A. Nordheim. 1990. Synergism in the ternary complex formation between the dimeric glycoprotein $\mathrm{p} 67^{\mathrm{SRF}}$, polypeptide $\mathrm{p} 62^{\mathrm{TCF}}$ and the c-fos serum response element. EMBO J. 9: 1123-1130.

Shaw, P.E., H. Schröter, and A. Nordheim. 1989. The ability of a ternary complex to form over the serum response element correlates with serum inducibility of the human c-fos promoter. Cell 56: 563-572.

Sheng, M., M.A. Thompson, and M.E. Greenberg. 1991. CREB: $\mathrm{A} \mathrm{Ca}^{2+}$-regulated transcription factor phosphorylated by calmodulin-dependent kinases. Science 252: 1427-1430.

Siegfried, Z. and E.B. Ziff. 1989. Transcription activation by serum, PDGF, and TPA through the c-fos DSE: Cell type specific requirements for induction. Oncogene 4: 3-11.

- 1990. Altered transcriptional activity of the c-fos promoter plasmids in v-raf-transformed NIH 3T3 cells. Mol. Cell. Biol. 10: 6073-6078.

Stumpo, D.J., T.N. Stewart, M.Z. Gilman, and P.J. Blackshear. 1988. Identification of $c$-fos sequences involved in induction by insulin and phorbol esters. I. Biol. Chem. 263: 1611-1614.

Treisman, R. 1985. Transient accumulation of c-fos RNA following serum stimulation requires a conserved 5 '-element and c-fos 3' sequences. Cell 42: 889-902.

- 1986. Identification of a protein-binding site that mediates transcriptional response of the c-fos gene to serum factors. Cell 46: 567-574.

- 1987. Identification and purification of a polypeptide that binds to the c-fos serum response element. EMBO $\%$ 6: 2711-2717.

Velcich, A. and E.B. Ziff. 1990. The FAP site of the c-fos promoter is a novel element related to CRE and AP-1 sites, which provides cell type specific transcriptional control. Mol. Cell. Biol. 10: 6273-6282.

Vosatka, R., A. Hermanowski-Vosatka, R. Metz, and E.B. Ziff. 1989. Dynamic interactions of c-fos protein in serum-stimulated 3T3 cells. J. Cell. Physiol. 138: 493-502.

Yamamoto, K.K., G.A. Gonzalez, W.H. Biggs III, and M.R. Montminy. 1988. Phosphorylation-induced binding and transcriptional efficacy of nuclear factor CREB. Nature 334: 495-498.

Yamamoto, K.K., G.A. Gonzalez, P. Menzel, J. Rivier, and M.R. Montminy. 1990. Characterization of a bipartite activation domain in transcription factor CREB. Cell 60: 611-617.

Zhang, Y., J.-X. Lin, Y.K. Yip, and J. Vilcek. 1988. Enhancement of cAMP levels and of protein kinase activity by tumor necrosis factor and interleukin-1 in human fibroblasts: Role in the induction of interleukin-6. Proc. Natl. Acad. Sci. 85: 6802-6805. 


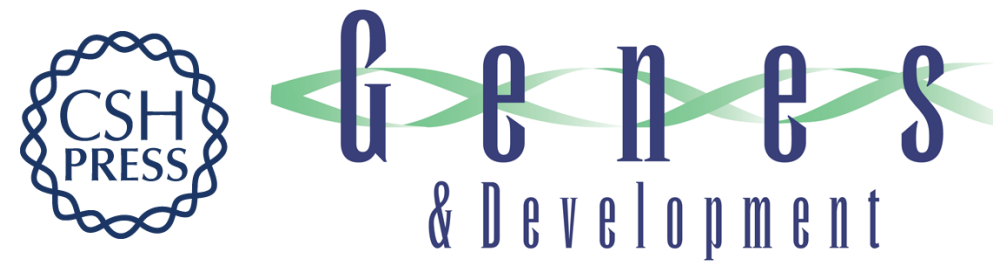

\section{CAMP stimulates the C/EBP-related transcription factor rNFIL-6 to trans-locate to the nucleus and induce c-fos transcription.}

R Metz and E Ziff

Genes Dev. 1991, 5:

Access the most recent version at doi:10.1101/gad.5.10.1754

References This article cites 62 articles, 33 of which can be accessed free at:

http://genesdev.cshlp.org/content/5/10/1754.full.html\#ref-list-1

License

Email Alerting

Service

Receive free email alerts when new articles cite this article - sign up in the box at the top right corner of the article or click here.

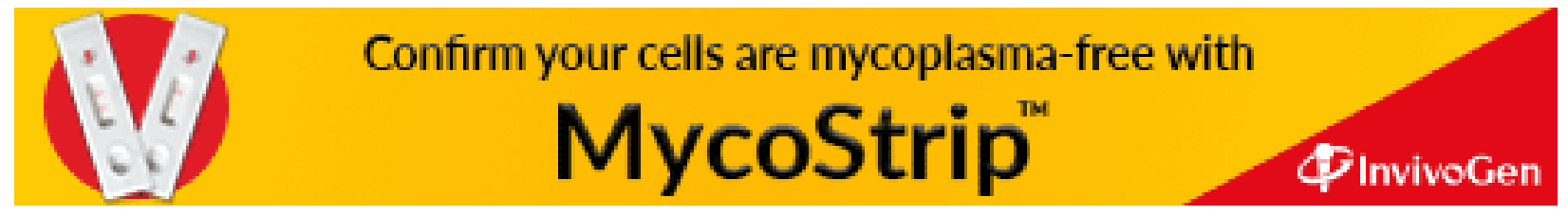

